\title{
Research into professional outcomes for psychotherapists trained at a centre for psychotherapy and transactional analysis in Italy
}

\author{
(C) 2015 Ugo De Ambrogio and Carla Dessi
}

\begin{abstract}
The authors developed a questionnaire and analysed professional outcomes for 98 former students who completed trainings in psychotherapy and transactional analysis, recognised by the Italian Ministry of University \& Research, during the past 15 years at the Centre of Psychology and Transactional Analysis in Milan. Statistical results were discussed with others and factors reviewed included how students managed in the world of work, and the positive results and critical elements of applying transactional analysis in psychotherapy. Professional life facts emerge in terms of a recognisable identity, ethical attention and satisfaction with the application of tools learned. Flexibility in coping with stimuli and issues met in professional practice, and the desire to have an exchange with colleagues and between different theoretical models, are also identified.
\end{abstract}

Editor's Note: this paper is an amended version of an article that appeared in Italian as De Ambrogio, Ugo \& Dessi, Carla (2010) Quale professione per gli psicoterapeuti, oggi? Ricerca sugli esiti professionali degli psicoterapeuti specializzati al Centro di psicologia e Analisi Transazionale di Milano published in Quaderni di Psicologia, Analisi Transazionale e scienze umane, 53 23-45. It appears here by kind permission of the publisher Dr Gerardo Mastrullo.

\section{Key Words}

Research, questionnaire, psychotherapy training, professional practice, transactional analysis training

\section{Introduction}

The Ministry for University \& Research recognised the Centre for Transactional Analysis in Milan in
1994 to run the Scuola di Specializzazione in Psicoterapia. This is an educational establishment with a transactional analysis approach and awards a diploma in psychotherapy (art 3 ex lege). This training institute in the past 15 years has had an intense educational activity, awarding diplomas to over 140 students, and supporting both their personal and professional development.

Aware of the importance of research in guiding and improving the quality of training, and of the rapid changes in work environments, in 2009 the Centre conducted this study with former students. The work aimed at observing closely the professional outcomes for the graduates, to understand the positive outcomes and any critique about the theory and application of transactional analysis. The researchers were supported by Susanna Ligabue and Anna Rotondo, both Teaching \& Supervising Transactional Analysts specialising in the field of Psychotherapy, and operated with the support of the former students and the teachers of the centre.

\section{Previous Literature}

At the time this study was conducted (2009) we found no previous literature about the impact of TA training on professional outcomes. Since then, a search for 'profession' in Ohlsson's (2010) 'Big List', where he listed details of TA research studies, generated entries only in terms of the biographical details of authors. A similar search in the online International Journal of Transactional Analysis Research leads only to an article by McQuaid (2015) which focuses on the experiences of students during training.

\section{Objectives}

The main objectives for the research were to: 
1. Draw a picture of the professional activity for the former students who had graduated in the past 15 years, considering the context (the training and the job market in Italy);

2. Evaluate the effectiveness of the training through exploring their satisfaction about:

a. comparison between outcomes and expectations;

b. effectiveness and use of the training and transactional analysis in particular, both in terms of the competencies acquired and as tools to manage the pressures of professional practice.

\section{Research method}

The research used a qualitative/quantitative approach, taking advantage of the complementarity between 'standard' analysis tools (the structured questionnaire) and 'non-standard' ones (a focus group and a workshop).

The study included 5 phases:

1. Definition of the dimensions to investigate and construction of the questionnaire.

2. Validation of the questionnaire through pre-test on a pilot group. Administration of the questionnaire to the sample.

3. Input and statistical analysis of data collected.

4. Data analysis and discussion of relevant aspects. This was completed with the participation of researchers, promoters and teachers during a workshop at the conference "Curare e prendersi cura" (Milan, 28 November 2009).

5. Writing of the research report and the present article.

Phases 1 and 2. We initially devised the questionnaire (Appendix 1) using the dimensions selected. The tool was tested by administering it to a pilot sample of psychotherapists specialised at the Scuola, equal to $7 \%$ of the entire population of former students.

This test revealed we needed to make the following amendments:

- Specification of the duration of the specialisation studies (enrolment year and graduation year).

- Insertion of choices to identify the professional title for the student at the time of enrolment (doctor or psychologist). We decided to make this change to investigate especially the category of doctors who chose to specialise in psychotherapy. Thus, each question linked to the professional status of the participant and we included in the final version one item specific to medical graduates.

- Insertion of questions aimed at expanding on the relationship between the times of verification for the learning of TA and their application within the participants' profession.

We also reorganised the questions to sections for the final version of the questionnaire. These were: Professional Profile; TA in your Profession, including questions on Continuing Professional Development; a General Considerations section; and a final Closing section about opinions, with some open questions.

Phase 3. The data collected after compilation of the final version of the questionnaire were inserted in a database provided by the SPSS (Statistical Package for Social Science) software. Subsequently they were analysed using:

a) Descriptive statistics (e.g. minimal values, maximal, average, median, mode);

b) Distribution of monovariant frequencies (e.g. gender, age etc.)

c) Distribution of bivariant frequencies (e.g. crosses between variables linked to professional development and some independent variables, such as number of years since acquisition of diploma, geographical area of origin, etc).

Phase 4. Having completed the statistical analysis of data, the results were discussed and analysed on two occasions. The first was between the researchers, promoters, and some teachers of the Scuola. The second was between researchers, promoters, some former students, some current students and other professionals attending the conference "Curarsi e prendersi cura" (Milan, 28 November 2009).

In both instances, we presented the first outcomes of the research and gave some points for discussion. This stimulated group participation and we collected various hypotheses of explanation for the results. Both discussions offered interpretations and suggestions for further exploration through secondary data analysis. 
The stimulating debates allowed us to think deeply and articulate the reflections we have included in the present article. The comments collected during the discussions added aspects we had not considered during our previous observations, allowing us to offer a richer and more articulated analysis of the data.

\section{The Sample}

The sample included 110 people selected amongst the 140 graduated psychotherapists of the last 15 years. For these 110 former students we had available sufficient details and we sent them a request to participate in the study by responding to the questionnaire. 98 of them responded within the specified timeframe of July to October, constituting $90 \%$ of the sample. We regarded return of a completed questionnaire as confirming informed consent to participate; as these were professionals rather than clients we did not feel the need to advise the right to withdraw from the research at any time.

This first result suggests a high interest in the former graduates of the Scuola to offer their opinion on their journey, and implies a strong sense of belonging to the Scuola as demonstrated by the subsequent research. We can also interpret this result as recognition for the contribution the Scuola made to their professional development.

The gender distribution of the sample was $75 \%$ female, $25 \%$ male. The average age was 42 years, with the most represented age range being 36-45 years. Only 9 were younger than 35 years and only 8 were older than 56 years. Distribution by age range is shown in Table 1.

\begin{tabular}{lcc}
\hline Ages (years) & Frequency & $\%$ \\
\hline Up to 35 & 9 & 9.2 \\
\hline From 36 to 45 & 65 & 66.3 \\
\hline From 46 to 55 & 16 & 16.3 \\
\hline From 56 to 65 & 7 & 7.1 \\
\hline Over 65 & 1 & 1.0 \\
\hline Total & 98 & 100.0 \\
\hline
\end{tabular}

Table 1 - Analysis of those interviewed by age

$45 \%$ of those questioned had graduated between 2 and 5 years before the study, ending their training between 2004 and 2007, and 30\% had graduated between 1998 and 2003. Having this kind of sample allowed us follow up the professional journeys of former students years after graduating.

Figure 1 shows the distribution of geographical origins of those interviewed. Most came from Lombardia (77 out of 98); some from other Northern

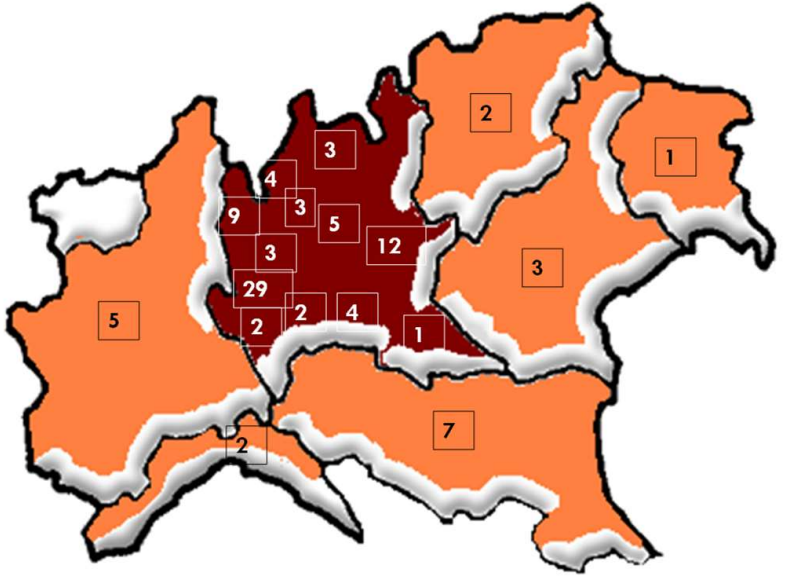

Figure 1: Geographical areas of origin of those interviewed.

counties, such as Emilia Romagna (7 coming from Bologna, Modena, Reggio Emilia, Piacenza) and Piemonte (5 coming from Biella, Novara and Verbania); and a small number came from Friuli Venezia Giulia, Liguria, Trentino Alto Adige and Veneto.

\section{Results}

Professional Profile

The first group of questions were aimed at individuating the professional profile for the participants, so as to understand whether psychotherapy is central to the professional activity of the interviewees and how they practice.

As presented in Table 2, the data shows $87 \%$ of therapists have a degree in psychology and $13 \%$ in medicine. When defining their own professional status currently, 9 out of 10 declared themselves to be psychotherapists. As well as the identity as psychotherapist most claim their identity of psychologist $(45 \%)$ and less frequently of trainer (18.4\%).

As each interviewee could indicate more than one answer, the table shows the percentages given by the ratio between frequency and number of valid responses.

The questionnaire explored how participants located themselves in the job market (Table 3). Overall, the professional circumstances of former graduates appeared stable for $77.7 \%$ of the interviewees: $49.5 \%$ defined themselves as established selfemployed and $28.2 \%$ as employed. $22.4 \%$ had some difficulties: two thirds of these had temporary contracts and the rest were self-employed within an unstable market. 


\begin{tabular}{lcc}
\hline & Frequency & $\begin{array}{c}\% \text { of } \\
\text { cases }\end{array}$ \\
\hline Psychotherapist & 89 & 90.8 \\
\hline Psychologist & 44 & 44.9 \\
\hline Trainer & 18 & 18.4 \\
\hline Doctor & 11 & 11.2 \\
\hline Other & 4 & 4.1 \\
\hline Educator & 3 & 3.1 \\
\hline Teacher & 3 & 3.1 \\
\hline $\begin{array}{l}\text { Organisational } \\
\text { Consultant }\end{array}$ & 2 & 2 \\
\hline Total & $\mathbf{1 7 4}$ & $\mathbf{1 7 7 . 6}$ \\
\hline
\end{tabular}

Table 2 - How the participants define themselves from the professional point of view. $n=98$

\begin{tabular}{lccccc}
\hline & $\begin{array}{c}\mathbf{1} \\
\text { year }\end{array}$ & $\begin{array}{c}\mathbf{2 - 5} \\
\text { years }\end{array}$ & $\begin{array}{c}\mathbf{6 - 1 0} \\
\text { years }\end{array}$ & $\begin{array}{c}\text { Over } \\
\mathbf{1 0} \\
\text { years }\end{array}$ & Total \\
\hline $\begin{array}{l}\text { Established } \\
\text { self } \\
\text { employed }\end{array}$ & 27.8 & 43.8 & 69.0 & 62.5 & 49.5 \\
\hline $\begin{array}{l}\text { Employed } \\
\text { Eelf- }\end{array}$ & 22.2 & 35.4 & 20.7 & 25.0 & 28.2 \\
\hline $\begin{array}{l}\text { employed } \\
\text { with } \\
\text { unstable } \\
\text { market }\end{array}$ & 11.1 & 8.3 & 6.9 & - & 7.8 \\
\hline $\begin{array}{l}\text { Temporary } \\
\text { contract }\end{array}$ & 38.9 & 12.5 & 3.4 & 12.5 & 14.6 \\
\hline Total & 100 & 100 & 100 & 100 & 100 \\
\hline
\end{tabular}

Table 3- the participants' position in the job market. Analysis per year of graduation $n=98$.

The stability of position in the job market decreased for those who had graduated more recently, with only $50 \%$ of the participants who graduated in the last year having a stable job.Comparing these data on the basis of respondents' university training, it emerged that psychologists had more precarious employment than doctors: $25.2 \%$ against $15.4 \%$.

Considering the geographical area of origin, Table 4 shows how former students who were in the county of Lombardia whilst training with the Scuola have somewhat higher stability in the job market for that region, with the percentage of uncertainly-employed graduates there being lower than for other areas $(21.5 \%$ against $25 \%$ in total).Because most respondents indicated that they had at least two professional functions (the average of the functions performed was 2.2), further analysis was conducted to ascertain how much time interviewees spent in the various professional activities. As shown in Table 5 , those who graduated in medicine spent $75 \%$ of their time functioning as a doctor, leaving only $25 \%$ of their time as a psychotherapist. Those who graduated in psychology indicated an equal distribution of time between the roles of psychotherapist and that of psychologist, educator or teacher.

\begin{tabular}{lc}
\hline & $\%$ average \\
\hline Psychotherapist & 51.0 \\
\hline Psychologist & 51.3 \\
\hline Trainer & 18.3 \\
\hline Doctor & 75.9 \\
\hline Educator & 45.8 \\
\hline Teacher & 43.3 \\
\hline Organisational Consultant & 35 \\
\hline Total & \\
\hline
\end{tabular}

Table 4 - Time dedicated by the interviewees to each function (\% average) $n=97$

\begin{tabular}{|c|c|c|c|c|c|c|c|}
\hline & Lombardy & Veneto & Piemonte & $\begin{array}{c}\text { Emilia- } \\
\text { Romagna }\end{array}$ & $\begin{array}{l}\text { Trentino } \\
\text { Alto } \\
\text { Adige }\end{array}$ & Liguria & $\begin{array}{c}\text { Friuli } \\
\text { Venezia } \\
\text { Giulia }\end{array}$ \\
\hline $\begin{array}{l}\text { \% of Established Self- } \\
\text { employed and employed in } \\
\text { public or private organisations }\end{array}$ & 78.4 & 66.7 & 60 & 71.4 & 100 & 100 & 100 \\
\hline $\begin{array}{l}\text { \% of self-employed with } \\
\text { uncertain market/employed } \\
\text { with temporary contracts in } \\
\text { public or private organisations }\end{array}$ & 21.6 & 33.3 & 40.0 & 28.6 & - & - & - \\
\hline
\end{tabular}

Table 5 - Geographical distribution of interviewed and their positioning in the job market. Data per region of origin. $n=98$ 
The average number of psychotherapy clients was 12 , for both medicine and psychology graduates; this is shown in Table 6 analysed per number of years (in ranges) since obtaining the specialisation in psychotherapy.

Interestingly, we noticed roughly half the sample had a maximum of 10 clients. There was a significant number of psychotherapists with more than 20 clients and occasionally more than 30 ; this may indicate an overload of daily clinical work.

\begin{tabular}{|c|c|c|c|c|c|}
\hline & $\begin{array}{c}1 \\
\text { year }\end{array}$ & $\begin{array}{c}2-5 \\
\text { years }\end{array}$ & $\begin{array}{c}6-10 \\
\text { years }\end{array}$ & $\begin{array}{c}\text { Over } \\
10 \\
\text { years }\end{array}$ & Total \\
\hline $\begin{array}{l}\text { Up to } 5 \\
\text { clients }\end{array}$ & 20.0 & 27.9 & 17.2 & - & 21.5 \\
\hline $\begin{array}{l}5-10 \\
\text { clients }\end{array}$ & 46.7 & 34.9 & 20.7 & 50.0 & 33.3 \\
\hline $\begin{array}{l}11-20 \\
\text { clients }\end{array}$ & 26.7 & 32.6 & 41.4 & 33.3 & 34.4 \\
\hline $\begin{array}{l}21-30 \\
\text { clients }\end{array}$ & - & 4.7 & 13.8 & - & 6.5 \\
\hline $\begin{array}{l}\text { More } \\
\text { than } 30 \\
\text { clients }\end{array}$ & 6.7 & - & 6.9 & 16.7 & 4.3 \\
\hline Total & 100 & 100 & 100 & 100 & 100 \\
\hline
\end{tabular}

Table 6 - number of clients per years since completing the diploma $n=93$

We then considered the contribution of the activity of psychotherapy to the psychotherapist's income, as shown in Table 7. In more than half the cases (53\%), psychotherapy provided over $51 \%$ of earnings and for $27.8 \%$ of these the contribution was of threequarters of their income.

However, for one interviewee in four (23 people distributed especially in the temporarily employed group and professionally (younger'), psychotherapy contributed less than $25 \%$ to their monthly revenue.

\begin{tabular}{lcc}
\hline & Frequency & $\%$ \\
\hline Over $75 \%$ & 25 & 27.8 \\
\hline $51-75 \%$ & 23 & 25.6 \\
\hline $25-50 \%$ & 19 & 21.1 \\
\hline Less than & 23 & 25.6 \\
\hline Total & 90 & 100.0 \\
\hline
\end{tabular}

Table 7 - Psychotherapy activity contribution to earnings. $n=90$
Considering the type of client for psychotherapy showed that the highest proportion are adults $(84.9 \%)$, with the next highest proportion being adolescents and young people (59.1\%). Table 8 shows the smaller proportions of other types of clients such as children, couples and families. Again, for this analysis the respondents could give more than one answer.

We also observed that 75 percent of interviewees indicated that they conducted psychotherapy exclusively in an individual setting. The remaining 25 percent indicated that group psychotherapy represented about one fifth of their overall psychotherapeutic activity.

\begin{tabular}{lcc}
\hline & Frequency & $\begin{array}{c}\% \text { of } \\
\text { cases }^{*}\end{array}$ \\
\hline $\begin{array}{l}\text { Adolescents and } \\
\text { young people }\end{array}$ & 55 & 59.1 \\
\hline Adults & 79 & 84.9 \\
\hline Children & 16 & 17.2 \\
\hline Couples & 13 & 14.0 \\
\hline Families & 5 & 5.4 \\
\hline Total & 168 & 180.6 \\
\hline
\end{tabular}

Table 8 - Main Types of psychotherapy clients. $n=$ 93

As shown in Table 9, on average $70 \%$ indicated that they had a network of contacts in the public or private sectors, such as local organisations and hospitals, for enquiries and referrals. The percentage was higher for new graduates, although it can be seen that such links are still there at the $50 \%$ level after many years.

\begin{tabular}{|l|c|c|c|c|c|}
\hline & $\begin{array}{c}\mathbf{1} \\
\text { year }\end{array}$ & $\begin{array}{c}\mathbf{2 - 5} \\
\text { years }\end{array}$ & $\begin{array}{c}\mathbf{6 - 1 0} \\
\text { years }\end{array}$ & $\begin{array}{c}\text { Over } \\
\mathbf{1 0} \\
\text { years }\end{array}$ & Total \\
\hline Yes & 87.5 & 61.9 & 75.0 & 50.0 & 69.6 \\
\hline No & 12.5 & 38.1 & 25.0 & 50.0 & 30.4 \\
\hline Total & 100 & 100 & 100 & 100 & 100 \\
\hline
\end{tabular}

Table 9 - Contact Networks and years since diploma

A related question provided the information that the organisation that gave the placement to the interviewee while they were a student of the Scuola represented the most significant of such contacts; two thirds of the respondents (65 cases or $66 \%$ ) had 
ongoing contacts with those organisations, and one quarter of the respondents (24 cases) collaborated with those organisations on a regular basis.

Further analysis of data per geographical area of origin and the contribution of psychotherapy to monthly income shows that:

- $\quad$ Therapists from Piemonte have the least links with other network members ( 1 in 3 cases);

- Belonging to a network allows having a larger number of clients; hence, psychotherapy work contributes more to the overall earning (Tables 10 and 11).

\begin{tabular}{lc}
\hline & Average number of clients \\
\hline Yes & 13.9 \\
\hline No & 8.3 \\
\hline
\end{tabular}

Table 10 - networks and average number of clients $n=91$

\begin{tabular}{|c|c|c|c|c|c|}
\hline & $\begin{array}{l}\text { Over } \\
75 \%\end{array}$ & $\begin{array}{c}51- \\
75 \%\end{array}$ & $\begin{array}{c}25- \\
50 \%\end{array}$ & $\begin{array}{l}\text { Less } \\
\text { than } \\
25 \% \\
\end{array}$ & total \\
\hline Yes & 36.1 & 24.5 & 19.7 & 19.7 & 100.0 \\
\hline No & 10.7 & 25.0 & 25.0 & 39.3 & 100.0 \\
\hline
\end{tabular}

Table 11- networks and contribution to earning $n=$ 89

Respondents were asked within the questionnaire about their professional activities as therapists in terms of ethics; specifically they were asked whether they had encountered any ethical or professional standards dilemmas associated with the activity of psychotherapy.

7 out of 10 declared they had encountered such issues, accessing supervision to address them $(66 \%$ of the cases), asking for support from other members of their clinical work groups $(32 \%)$, contacting their professional organisation (29\%), and discussing them with peers $(22 \%)$. Overall, this result indicates that the therapists are taking fully into account the inevitable ethical challenges deriving from the activity of psychotherapy: a significant $70 \%$ recognised these problems and had the tools to tackle them.

To conclude this part of the questionnaire we requested a personal judgment on their professional situation relating to motivation, income, professional stability and their specialism in psychotherapy. Figure 2 offers an overall picture of psychotherapists who are in general happy with these, although there are considerable minorities who indicate dissatisfaction about their income and their professional stability.

\section{TA and Your Profession}

The second part of the questionnaire was dedicated to the use of TA in psychotherapy.

As we can see in Table 12, $96 \%$ of responders regarded TA as their main framework. Only 4 cases considered TA complementary to another approach which they considered their main one, such as cognitive behavioural, psychodynamic, psychoanalytic, systemic or Gestalt.

\begin{tabular}{lcc}
\hline TA is... & Frequency & $\%$ \\
\hline $\begin{array}{l}\text { My prevalent professional } \\
\text { approach }\end{array}$ & 94 & 95.9 \\
\hline $\begin{array}{l}\text { Complementary to another } \\
\text { approach I consider } \\
\text { prevalent }\end{array}$ & 4 & 1.4 \\
\hline Total & 98 & 100 \\
\hline
\end{tabular}

Table 12 - Use of TA in psychotherapy

We investigated in more detail the TA theoretical tools most utilised by the therapists, as seen in Table 13.

\begin{tabular}{|cl|c|c|}
\hline & Frequency & $\begin{array}{c}\% \text { of } \\
\text { cases }\end{array}$ \\
\hline 1. & Script & 64 & 72.7 \\
\hline 2. & Ego States & 62 & 70.5 \\
\hline 3. & Contracting & 50 & 56.8 \\
\hline $4 . \quad$ Games & 45 & 51.1 \\
\hline 5. & Transactions & 25 & 28.4 \\
\hline 6. & Strokes & 22 & 5.0 \\
\hline 7. & Discounting & 15 & 17.0 \\
\hline 8. Berne's Operations & 13 & 14.8 \\
\hline 9. & Drama triangle & 10 & 11.4 \\
\hline 10. Impasses & 7 & 8.0 \\
\hline 11. Rackets & 6 & 6.8 \\
\hline 12. & Passivity & 5 & 5.7 \\
\hline 13. Egograms & 5 & 5.7 \\
\hline 14. Okness & 5 & 5.7 \\
\hline 15. & Functional diagnosis & 5 & 5.7 \\
\hline
\end{tabular}

Table 13 - TA tools most utilised in psychotherapy. $n=88$ 


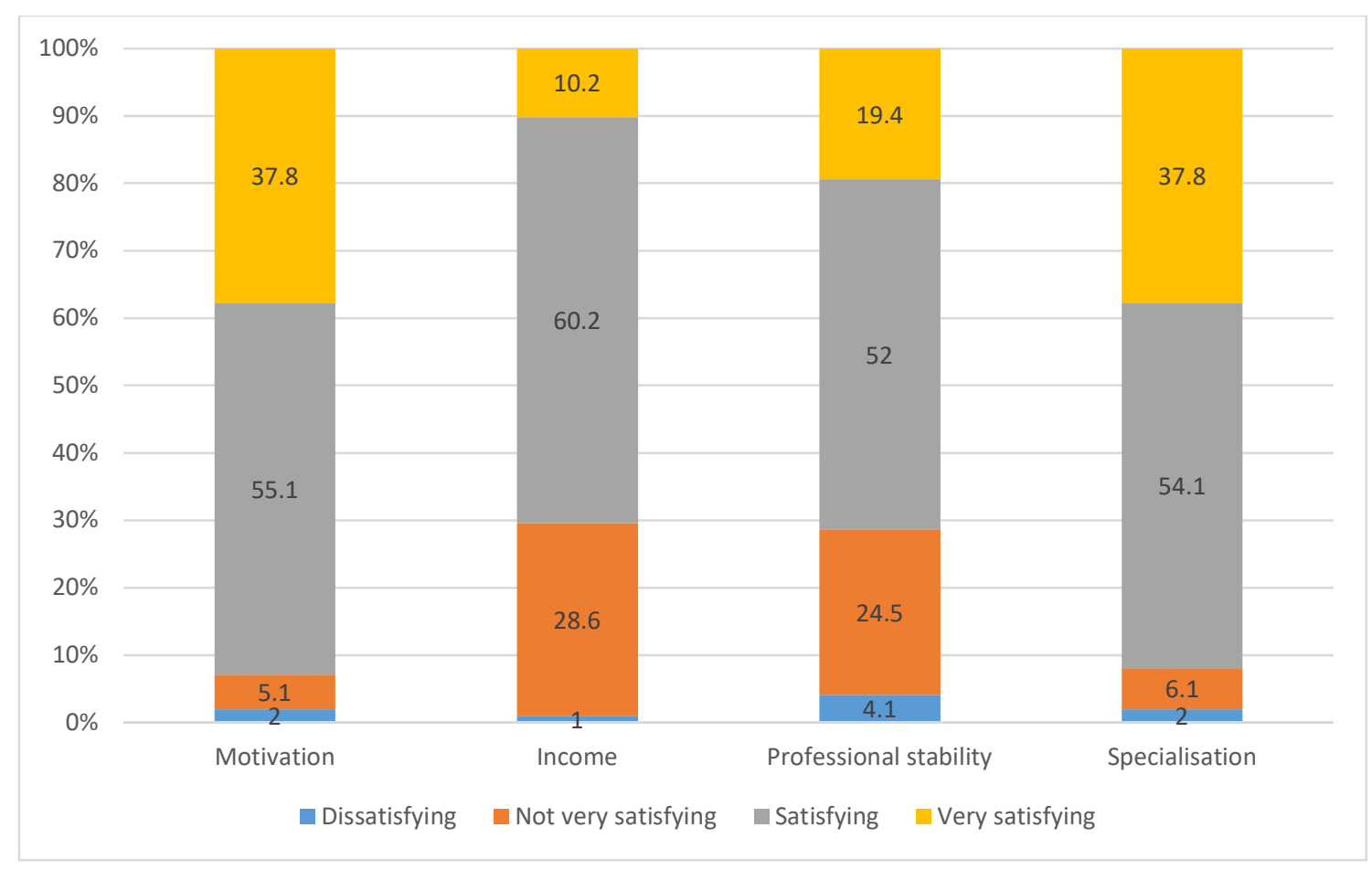

Figure 2 - Overall satisfaction of the interviewee, relative to their professional position. $n=98$

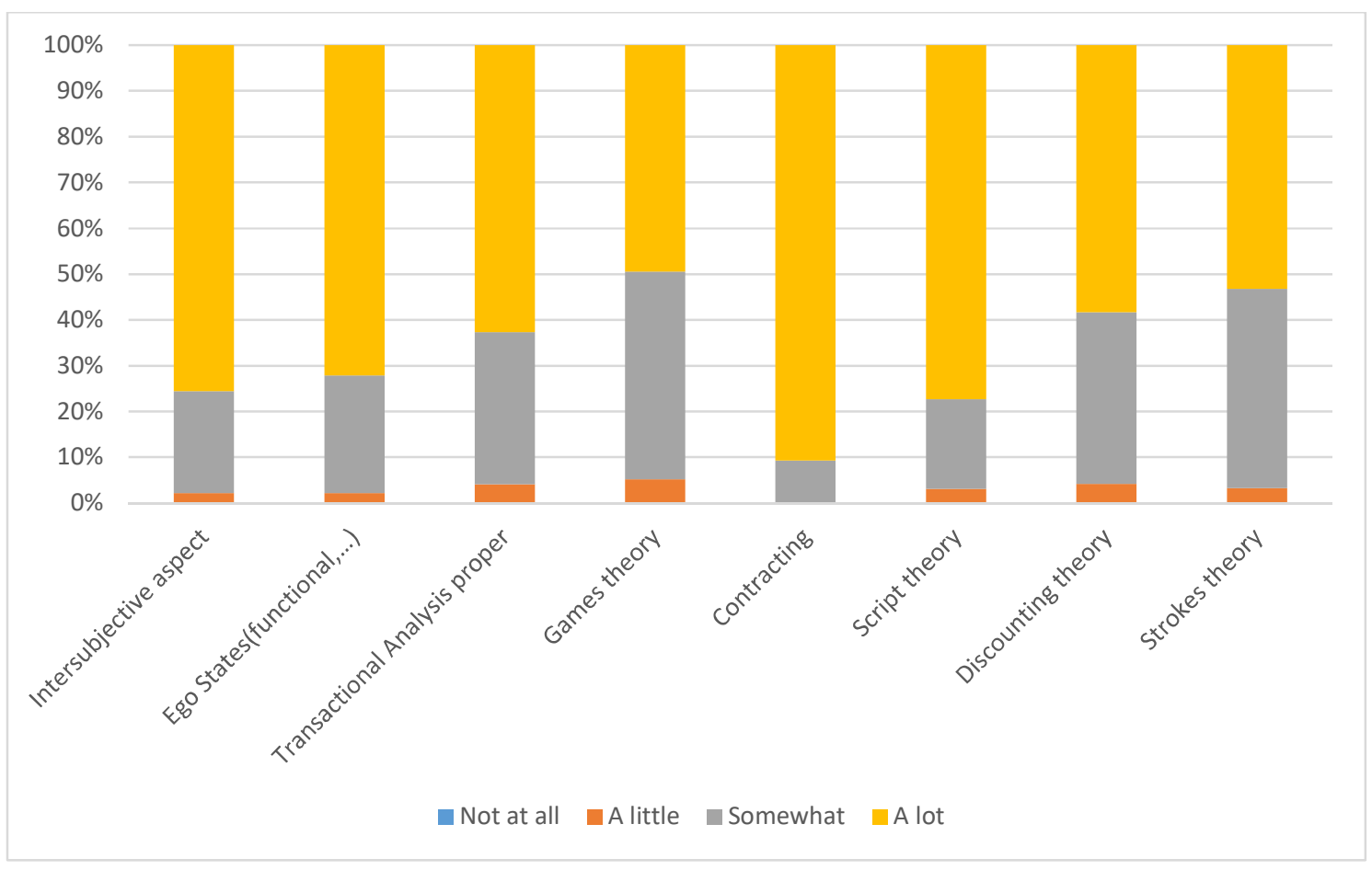

Figure 3 - How vaild the interviewee considers the main aspects of TA to be. $n=98$ 
There were numerous (15) TA tools utilised by at least $89.8 \%$ of the interviewees; amongst these the most represented are:

- $\quad$ Script (64 cases equal to $73 \%$ of respondents);

- Ego States (62 cases equal to $70 \%$ of respondents);

- Contracting (50 cases equal to $57 \%$ of respondents);

- Games (45 cases equal to $5 \%$ of respondents).

Coherently with this intensive utilisation of TA theory and its tools, the interviewees expressed favourable comments in relation to the effectiveness and contemporaneousness of TA. In fact, all the answers to the question "Indicate what and how much you rate TA valid today" specified they considered TA valid in each of its aspects, even with the small variations represented in Figure 3.

It is noteworthy that within a picture of strong validity of TA for all the dimensions proposed, contracting represents the aspect most recognised: $90 \%$ of cases replied "A lot" and none replied it was of little validity. This particular interest in contracting emerges also from the answers to another question. We asked which learning the participants considered important amongst the various teachings received at the Scuola. They indicated Contracting as the most significant (39 cases, equal to $39.8 \%$ ), followed by Okness (20 cases equal to $20.4 \%$ ), Intersubjectivity (17 cases equal to $17.3 \%$ ), Script theory (10 cases, equal to $11.2 \%$ ), and reciprocity (10 cases, equal to $10.2 \%)$.

Concluding the observations on the use of TA in psychotherapy, one of the last questions asked in the section was whether they would still choose to specialise in TA if they could go back in time. 86 people $(90 \%)$ answered "Without a doubt", none answered "No" and only 9 people (10\%) "Probably, but with reservations".

These results suggest a powerful recognition of TA in the personal growth and professional development of the participants. TA theory is a strong reference for the psychotherapists and they consider it the prevalent approach for their professional activity, also using many of the tools the theory offers.

Table 14 shows the answers given by the participants to the question on how they position TA in terms of contemporariness, flexibility, vision and theoretical-technical solidity, using a scale from 1 to 10. The averages of the scores recorded confirm the favourable positioning of the approach, which they

\begin{tabular}{|l|c|l|}
\hline & $\begin{array}{c}\text { Average } \\
\text { score }\end{array}$ & TA is out of date \\
\hline $\begin{array}{l}\text { TA is a } \\
\text { contemporary } \\
\text { approach (value = 1) }\end{array}$ & 2.5 & $\begin{array}{l}\text { TAlue }=10) \\
\text { (valu }\end{array}$ \\
\hline $\begin{array}{l}\text { TA is flexible (value } \\
=1)\end{array}$ & 2.0 & $\begin{array}{l}\text { TA is rigid (value }= \\
10)\end{array}$ \\
\hline $\begin{array}{l}\text { TA has a wide vision } \\
\text { (value = 1) }\end{array}$ & 2.2 & $\begin{array}{l}\text { TA has a limited } \\
\text { vision (value }=10)\end{array}$ \\
\hline $\begin{array}{l}\text { TA is a solid } \\
\text { theoretical-technical } \\
\text { approach } \\
\text { (value = 1) }\end{array}$ & 2.7 & $\begin{array}{l}\text { TA is a weak } \\
\text { theoretical- } \\
\text { technical } \\
\text { approach (value }= \\
10)\end{array}$ \\
\hline
\end{tabular}

Table 14 - How the interviewees considered

TA currently.

considered current, solid and sufficiently flexible to be adapted to the work of psychotherapy.

Finally, in this section of the questionnaire the responses to Question 21 indicated that $45 \%$ of the interviewees had progressed in their TA training, mainly to become endorsed as Certified Transactional Analyst (Psychotherapy). Responses to question 22 indicated that all interviewees were involved in CPD, with 9 out of 10 engaged in reading, 8 out of 10 participating in conferences and seminars, and 7 out of 10 engaging in regular supervision.

Final Section of Questionnaire

In the final section of the questionnaire, we included open questions about the most and least satisfying aspects of the professional experience gained so far. For the most satisfying aspect, 18 interviewees indicated engagements and interaction with clients, 18 commented on working in dialogue and collaboration with colleagues in other professions, 15 selected learning opportunities through research and 13 had flexibility and openness of the TA approach. For the least satisfactory aspects, 16 interviewees indicated loneliness, isolation, difficulties in working with others and lack of contacts. 13 wrote of issues due to uncertain employment conditions and 11 commented directly on financial difficulties.

\section{Limitations}

The obvious limitation of this study is the fact that it involved the former students of only one training institute. The researchers were closely associated with that institute, the questionnaire as published was clearly issued by that institute and it began with a question that reminded respondents that they were being sent the questionnaire because of their 
previous attendance at the Institute. We should expect, therefore, that respondents are likely to have been influenced into giving responses that would reflect positively on the institute. However, the questionnaire would also have provided an opportunity for any former student with a grievance toward the institute to have indicated this in their responses.

The fact that respondents had spent time and money obtaining their TA training, and in many cases had continued to do so, made them a restricted sample with a frame of reference that means it is unlikely that they would have ceased applying what they had put so much effort and money into acquiring.

The limitation of the study to one training institute meant also that it was limited to one geographical area. The map included as Figure 1 indicates that the respondents were all operating within a limited number of counties within Italy. It is hoped that provision of the questionnaire as an appendix to this paper will enable similar research to be undertaken elsewhere.

The study was undertaken during the economic and social conditions that applied in a specific geographical area and a specific country during 2009.

\section{Conclusions}

This research has provided significant indications regarding the professional outcomes for former students, how their professional profiles are constructed, and how they perform their professional activity. The latter includes the theoretical aspects (how they use TA theory), the methodology (which TA tools they employ) and the ethics. We were able to obtain a sample that represented the graduates of the Scuola, allowing us to present a wide picture that represents a follow up of the graduates' professional journeys years after they completed their training.

From the analysis of the professional profiles, we constructed an image that revealed professionals with a strong identity, practising within contractual arrangements. They have specific attitudes and competencies that guarantee efficiency in their work, such as being part of a network and the understanding of ethical aspects. Lastly, the vast majority of the interviewees declared that they obtain both financial and personal recognition through their work.

What emerges is a strong sense of belonging to TA and to the Scuola, and we can identify much learning obtained through the training. TA theory seems to be a solid base for the professional journey in almost all cases, and the principal approach utilised in the psychotherapy practice. The main results of the research show a strong and long lasting bond between former students, most of whom are now established clinicians, and their speciality training.

Although this research has been limited to the former students of a specific training Institute, we hope that the inclusion with this paper of our questionnaire will prompt and enable other researchers to repeat this process elsewhere. This will increase the awareness within the transactional analysis community of the impact of the qualifying processes of transactional analysis upon the practitioners, which will add an important dimension to research into the outcomes for clients.

Ugo De Ambrogio is a Teaching \& Supervising Transactional Analyst (Organisational), a Sociologist and the President of the Institute for Social Research (Irs), in Milan. He can be contacted on udeambrogio@irsonline.it

Carla Dessi is a Sociologist and a researcher for the Institute for Social Research (Irs), Milan. She can be contacted on cdessi@irsonline.it

\section{References}

Corbetta, P. (1999) Metodologia e tecniche della ricerca sociale, Bologna: II Mulino.

Di Franco, G. (2001) EDS: Esplorare, descrivere e sintetizzare i dati. Guida pratica all'analisi dei dati nella ricerca sociale, Milano: FrancoAngeli.

Marradi, A. (1984) Concetti e metodi per la ricerca sociale, Firenze: La Giuntina

McQuaid, Cathy (2015) An investigation into the factors that influence the perceived experiences and outcomes for students training in Transactional Analysis Psychotherapy in the UK and USA International Journal of Transactional Analysis Research 6:1 28-53

Ohlsson, Thomas (2010) Scientific evidence base for transactional analysis in the year 2010: Annex 1 - the Big List: References to Transactional Analysis research 19632010 International Journal of Transactional Analysis Research 1:1 4-11 


\section{Appendix: Translation of Questionnaire}

1. You are...

Male Medical Doctor

Female Psychologist

2. When did you attend the "Scuola di specializzazione in Psicoterapia"?

Year of enrolment ....

Year of graduation ...

3. You were born in....

4. You live in (city)....

PROFESSIONAL PROFILE

5. How do you now define your professional status? ( $\max 2$ answers)

Organisational consultant

Counsellor

Trainer

Educator

Teacher

Medical Doctor

Psychologist

Psychotherapist

Other (specify):

6. What is your professional status? (one answer only)

I am an independent professional with a solid market

I work as an employee in a public organisation (Asl, Local authority, Hospital)

I work as an employee in a private organisation (company, co-operative, association, etc)

I work with a temporary contract, mostly for one organisation in the public sector

I work with a temporary contract, mostly for one organisation in the private sector

I work with temporary contract with several organisations/clients, with an uncertain market

Other (specify)

7. Which of these professional roles do you cover, and in which percentages?

Organisational consultant

Counsellor

Trainer

Educator

Teacher

Doctor (specify whether GP, paediatric specialist, consultant, psychiatrist, etc)

Psychologist (specify whether educational, occupational, clinical, etc)

Psychotherapist

Other (specify): 
8. How many clients do you see for psychotherapy currently?

Number:

If you do not currently see any clients, go to question 13

9. What is the percentage contribution of psychotherapy work to your monthly income?

Over $75 \%$

Between 51 and $75 \%$

Between 25 and $50 \%$

Less than $25 \%$

10. Indicate your main client groups for psychotherapy (max 2 choices)

Adolescents and young people

Adults

Older people

Children

Couples

Families

Other (specify)

11. Are you in a network of contacts with public or private organisations (local or hospital) for referrals?

Yes No

12. Do you offer group psychotherapy?

Yes No

12 a. If you do, in what percentage compared to individual therapy?

Individual $\%$

Group \%

13. In your work as a psychotherapist have you encountered ethical or deontological issues?

Yes No

13 a. Who have you approached then? For example, your professional body, a solicitor, your clinical associates, your supervisor etc.

14. Overall, how do you consider yourself professionally in the following areas?

\begin{tabular}{|l|l|l|l|l|}
\hline & Unsatisfying & Not very satisfying & Satisfying & Very satisfying \\
\hline Your motivation & & & & \\
\hline Income & & & & \\
\hline Professional stability & & & & \\
\hline $\begin{array}{l}\text { Your specialism in } \\
\text { psychotherapy }\end{array}$ & & & & \\
\hline
\end{tabular}




\section{TA AND YOUR PROFESSION}

15. How do you consider TA today in your professional role?

I consider TA my main frame of reference in my professional role and I integrate it with other approaches Indicate which theories you integrate with TA .....

I consider TA a part of my professional training, which had as frame of reference another theoretical approach Indicate which....

16. How do you use TA in the following professional activities? (Answer only for those professional activities you have indicated in question 7)

\begin{tabular}{|l|l|l|l|l|}
\hline & A lot & Somewhat & A little & Not at all \\
\hline Organisational consultant & & & & \\
\hline Counsellor & & & & \\
\hline Trainer & & & & \\
\hline Educator & & & & \\
\hline Teacher & & & & \\
\hline Medical Doctor & & & & \\
\hline Psychologist & & & & \\
\hline Psychotherapist & & & & \\
\hline Other (specify) & & & & \\
\hline
\end{tabular}

17. When you use TA professionally, how do you do it?

\begin{tabular}{|l|l|l|}
\hline $\begin{array}{l}\text { Mainly overtly, sharing theory and } \\
\text { tools with clients and agency }\end{array}$ & $\begin{array}{l}\text { Mainly implicitly, analysing processes } \\
\text { and choosing options for behaviours }\end{array}$ & \begin{tabular}{l} 
Both explicitly and implicitly \\
\hline
\end{tabular} \\
\hline
\end{tabular}

18. Specify here which TA tools you use most often in your work as psychotherapist, if you do:

19. Where would you place TA in the following continuums?

\begin{tabular}{|l|llllllllll|l|}
\hline It is contemporary & 1 & 2 & 3 & 4 & 5 & 6 & 7 & 8 & 9 & 10 & It is dated \\
\hline It is flexible & 1 & 2 & 3 & 4 & 5 & 6 & 7 & 8 & 9 & 10 & It is rigid \\
\hline It offers an ample view & 1 & 2 & 3 & 4 & 5 & 6 & 7 & 8 & 9 & 10 & It offers a limited view \\
\hline $\begin{array}{l}\text { It has a solid theoretical and technical } \\
\text { base }\end{array}$ & 1 & 2 & 3 & 4 & 5 & 6 & 7 & 8 & 9 & 10 & $\begin{array}{l}\text { It has a weak theoretical and } \\
\text { technical base }\end{array}$ \\
\hline
\end{tabular}


20. Evaluate the validity of TA in the following aspects:

\begin{tabular}{|l|l|l|l|l|}
\hline & A lot & Somewhat & A little & \\
\hline $\begin{array}{l}\text { The intersubjective } \\
\text { vison linked to its } \\
\text { philosophy }\end{array}$ & & & & \\
\hline $\begin{array}{l}\text { Ego states (functional } \\
\text { and structural) }\end{array}$ & & & & \\
\hline $\begin{array}{l}\text { Analysis of } \\
\text { transactions }\end{array}$ & & & & \\
\hline Game theory & & & & \\
\hline Contractual method & & & & \\
\hline Script theory & & & & \\
\hline $\begin{array}{l}\text { Discounting and } \\
\text { passivity theory }\end{array}$ & & & & \\
\hline Stroke theory & & & & \\
\hline Other (specify) & & & & \\
\hline
\end{tabular}

21. Did you continue your TA training?

Yes No

21 a. If you did, how?

I am a contractual trainee for CTA

I am a Certified Transactional Analyst (CTA)

I am a Provisional Teaching and Supervising Transactional Analyst (PTSTA)

I am a Teaching and Supervising Transactional Analyst (TSTA)

Other (specify)

22. How do you keep yourself up to date and supported professionally? (You can select several responses)

Reading specialist books and journals

Regular supervision

Attending conferences and seminars

Attending team meetings with colleagues

Informal peer support

Other (specify)

23. Do you belong to professional associations or organisations in Italy or internationally specific to TA?

Yes No

23 a. If you do, which ones?

24. Do you belong to other professional associations or organisations in Italy or internationally? Yes No

24 a. If you do, which ones? 
25. Did you have further contacts with the agency where you completed your placement?

Yes No

25 a. If you do, of which kind?

I work continually for the agency, as an employee or internal collaborator

I regularly collaborate or interact professionally with the agency

I occasionally collaborate or interact professionally with the agency

I maintain an informal relationship with my colleagues within the agency

Other (specify)

\section{GENERAL CONSIDERATIONS}

26. On balance of your expectations regarding your professional development, which ones did you have when you started your training in TA? Which expectations did you have on completing your specialisation? Which expectations do you have today, taking into account your professional context, the market you can access and the needs you encounter?

My expectations of professional development when I started the TA training at the Scuola di TA were:

My expectations of professional development when I completed the training at the Scuola di TA were:

My expectations of professional development today are:

27. How do you rate your overall satisfaction concerning those expectations?

\begin{tabular}{|l|l|l|l|l|}
\hline & Very satisfied & $\begin{array}{l}\text { Somewhat } \\
\text { satisfied }\end{array}$ & A little satisfied & Unsatisfied \\
\hline $\begin{array}{l}\text { Compared to the expectations I had } \\
\text { when I started my training at the } \\
\text { Scuola }\end{array}$ & & & & \\
\hline $\begin{array}{l}\text { Compared to the expectations I had } \\
\text { when I finished my training at the } \\
\text { Scuola }\end{array}$ & & & & \\
\hline $\begin{array}{l}\text { Compared to the expectations I } \\
\text { have nowadays, considering the } \\
\text { professional context and today's } \\
\text { job market }\end{array}$ & & & & \\
\hline
\end{tabular}


28. Evaluate the following statements regarding your current occupation:

\begin{tabular}{|c|c|c|c|c|}
\hline & Completely agree & Somewhat agree & Disagree a little & Disagree totally \\
\hline Is coherent with the training & & & & \\
\hline $\begin{array}{l}\text { Stimulates me to develop } \\
\text { professionally }\end{array}$ & & & & \\
\hline Is a prestigious occupation & & & & \\
\hline $\begin{array}{l}\text { Is an occupation which offers wor } \\
\text { stability }\end{array}$ & & & & \\
\hline Mirrors my cultural interests & & & & \\
\hline It is a job that benefits society & & & & \\
\hline $\begin{array}{l}\text { Allows me to organise my work } \\
\text { professionally with autonomy and } \\
\text { independence }\end{array}$ & & & & \\
\hline Allows me to work flexible hours & & & & \\
\hline Allows me to enjoy free time & & & & \\
\hline Gives me a good income & & & & \\
\hline Allows me to have a career & & & & \\
\hline $\begin{array}{l}\text { Offers the opportunity to cultivate } \\
\text { good relationships with colleague }\end{array}$ & & & & \\
\hline $\begin{array}{l}\text { Consents me to work in pleasant } \\
\text { places and environments }\end{array}$ & & & & \\
\hline
\end{tabular}

And to complete.....

29. Write 3 key words expressing 3 important learnings gained at the Scuola:

30. In general terms, indicate 3 aspects you consider positive of the Scuola, and 3 negative ones:

\begin{tabular}{|l|l|}
\hline POSITIVE ASPECTS & NEGATIVE ASPECTS \\
\hline & \\
& \\
\hline
\end{tabular}


31. Which are the most and the least satisfying aspects of your professional experience?

\begin{tabular}{|l|l|}
\hline SATISFYING ASPECTS & DISAPPOINTING ASPECTS \\
\hline & \\
& \\
\hline
\end{tabular}

32. Evaluate the following statements concerning Psychotherapy speciality training establishments.

\begin{tabular}{|c|c|c|c|c|c|}
\hline & $\begin{array}{l}\text { Definitely } \\
\text { agree }\end{array}$ & $\begin{array}{l}\text { Somewhat } \\
\text { agree }\end{array}$ & $\begin{array}{l}\text { Disagree a } \\
\text { little }\end{array}$ & $\begin{array}{l}\text { Completely } \\
\text { disagree }\end{array}$ & $\begin{array}{l}\text { I don't want } \\
\text { to answer }\end{array}$ \\
\hline $\begin{array}{l}\text { These establishments, as they are } \\
\text { structured nowadays in Italy, } \\
\text { educate people who will work } \\
\text { mainly as psychotherapists }\end{array}$ & & & & & \\
\hline $\begin{array}{l}\text { The number of training } \\
\text { organisations is excessive, } \\
\text { considering the current job market }\end{array}$ & & & & & \\
\hline $\begin{array}{l}\text { There are too many training } \\
\text { establishments and as such they } \\
\text { produce gullible and unemployable } \\
\text { people }\end{array}$ & & & & & \\
\hline $\begin{array}{l}\text { They are important because they } \\
\text { offer a solid base to work } \\
\text { professionally, even in other } \\
\text { professional occupations }\end{array}$ & & & & & \\
\hline $\begin{array}{l}\text { They are obsolete, today } \\
\text { psychologists need to train more } \\
\text { specifically and with flexibility in } \\
\text { order to meet the demands of the } \\
\text { job market and the needs of the } \\
\text { clients }\end{array}$ & & & & & \\
\hline
\end{tabular}

33. If you could go back in time, would you choose again to train at a Psychotherapy training establishment?

Yes, certainly

Probably I would, but with some hesitation

No, I would make different choices (specify)

34. If you decided to specialise again in Psychotherapy, would you choose TA?

Yes, certainly

Probably I would, but with some hesitation

No, I would make different choices (specify)

Space for your personal comments and reflections:

Many thanks for your collaboration! 